\title{
Beneficial effectiveness of probiotic-low-fat ice cream containing Krueo Ma Noy (Cissampelos pareira L.) gum on colon microbiome under a dynamic gut model
}

\author{
${ }^{1}$ Kemsawasd, V. and ${ }^{2 *}$ Chaikham, $P$. \\ ${ }^{1}$ Institute of Nutrition, Mahidol University, Nakorn Pathom campus, Nakorn Pathom 73170, Thailand \\ ${ }^{2}$ Division of Food Science and Technology, Faculty of Science and Technology, Phranakhon Si Ayutthaya \\ Rajabhat University, Phranakhon Si Ayutthaya 13000, Thailand
}

\section{Article history:}

Received: 10 February 2019

Received in revised form: 12

March 2019

Accepted: 14 March 2019

Available Online: 27 March 2019

\section{Keywords:}

Bifidobacterium lactis $\mathrm{Bb}-12$, Krueo Ma Noy,

Gut model,

Colon microbiome,

Low-fat ice cream

\section{DOI:}

https://doi.org/10.26656/fr.2017.3(5).068

\begin{abstract}
The combined effects of low-fat ice cream supplemented with Bifidobacterium lactis $\mathrm{Bb}$ 12 and Krueo Ma Noy gum (KMN) in modulating the gut microbiota of a dynamic gut model were evaluated. Experimental trials were held to assess overall microbial metabolites (i.e. short-chain fatty acids, lactic acid, ammonia and biogenic amines) and colon microbial populations of lactobacilli, bifidobacteria, clostridia, fecal coliforms and total anaerobes. Low-fat ice cream was either administered into the simulated system alone, with probiotic $B$. lactis $\mathrm{Bb}-12, \mathrm{KMN}$ or both. Combined supplementation of low-fat ice cream with KMN and probiotic was shown to enhance the levels of beneficial microbial metabolites, viz. acetic, propionic, butyric and lactic acids, in proximal and distal colon vessels, while lowering the levels of ammonia and biogenic amines (i.e. cadaverine, putrescine, methylamine and tyramine) secretion as compared to pure low-fat ice cream. Observing from generated profiles of the colon microflora, the combined treatment yielded the greatest increase in populations of colon lactobacilli and bifidobacteria while suppressing the growth of fecal coliforms, clostridia and other harmful microbes. Such findings indicate the synbiotic potential and beneficial health effects of KMN and probiotic in low-fat ice cream in improving gut conditions.
\end{abstract}

\section{Introduction}

Functional foods, also known as foods exerting beneficial effects on specific organs or systems within the human body, are known for a variety of functions beyond energy and nutrient provision (Granato et al., 2010). In the present day, growing numbers of healthconcerned consumers fueled the rapid expansion of functional foods in the market, especially probiotic dairy products. In terms of functional foods, dairy products are strongly linked to probiotics. Probiotic strains have become of prominent interest in food product development due to its various properties, such as bacteriocin production, acid and bile tolerance, epithelial cell adherence, gut survivability and colonization, and endurance to physiochemical conditions of food processing and storage, which contribute to numerous benefits on human health (Prado et al., 2008). Such benefits are attributed by their antimicrobial, antimutagenic, anticarcinogenic and antihypertension properties. Regular ingestion has been shown to reduce symptoms of food allergy, stabilize host gut microflora and stimulate gut resistance to pathogens (Liong et al.,
2009; Granato et al., 2010).

Dairy products, viz. probiotic yogurts, fermented beverages and ice cream, are regarded as the main vehicles of probiotic supplementation and subsequent ingestion. According to Shah (2007), at least $10^{6} \mathrm{CFU} / \mathrm{g}$ of probiotic cells should be present in a dairy food to compensate subsequent population reduction during passage along the human gut. Probiotic supplemented ice cream has been reported to promote promising health benefits (Çaglar et al., 2008) and may potentially serve as vehicles and protective barriers for probiotics during gut transport (Cruz et al., 2009). The prevalence of noncommunicable diseases, such as obesity and cardiovascular disease, has led to towards the innovation and development of low-fat ice cream formulations containing probiotic cultures, prebiotics and synbiotics (Akalin and Erisir, 2008; Chaikham and Rattanasena, 2017).

Krueo Ma Noy (Cissampelos pareira L.) is a woody, climbing medicinal plant of the Menispermaceae family indigenous to the tropical area of Asia, East Africa and South Africa. This plant grows abundantly in the 
Northern and Northeastern regions of Thailand. Due to its analgesic properties, the Krueo Ma Noy plant was commonly used by indigenous people to treat a number of ailments, including sores, asthma, dysentery, diuretic and traumatic pain (Vardhanaburi and Ikeda, 2006). Cold -water extraction of the leaves produced a dark green gel with cooling properties that can be used to treat fever. Gel formation occurred within a very short time after the extraction process, resulting from unique characteristics of Krueo Ma Noy pectin, a complex polysaccharide examined in the reports of Singthong et al. $(2004,2005)$. Pectin is commonly applied in food production and manufacturing processes as gelling and thickening agents (Barros et al., 2002). The water-soluble fiber is one of the major substrates in the colonic bacteria metabolism of carbohydrate hydrolysis to produce organic byproducts, such as short-chain fatty acids (SCFA) and lactic acid (Slavin, 2013). Citrus pectin hydrolysate has been shown to exhibit prebiotic effects on tested non-fat milk probiotics, as demonstrated by growth enhancement, increased fermentation, and high levels of probiotic survivability (Ho et al., 2017).

Many researchers have incorporated dynamic models of the gastrointestinal system in the study of various probiotic functional foods, prebiotics and prebiotic candidates regarding their effects on colon bacteria viability, microbial composition and metabolite synthesis (Mäkivuokko et al., 2006; Mäkivuokko et al., 2007; Chaikham et al., 2012; Bianchi et al., 2014; Apichartsrangkoon et al., 2015). Different in vitro gut models were used predominantly in nutrition studies involving compositional analysis of the colon microbial community. Normally, they are comprised of different segments of the human gastrointestinal tract, including stomach, small intestinal and colon compartments, with a stable microbial community resembling the human gut microbiota or conditions (Kontula et al., 2002; Possemiers et al., 2010; Sivieri et al., 2013). Probiotic administration has been shown to enhance the modulatory effects of low-fat ice cream on simulated microbial ecosystems of the gastrointestinal tract (Chaikham and Rattanasena, 2017). While the fermentation of different prebiotics and prebiotic candidates on probiotic foods have been subjected to the similar simulation systems, there are currently insufficient studies attributing to the potential prebiotic effects of Krueo Ma Noy gum (KMN). Therefore, the objective of this study was to examine the combined ability of KMN and Bifidobacterium lactis Bb-12 supplementation along with low-fat ice cream in adjusting microbial compositions of the simulated gut model. Colon microbial diversities were determined by monitoring the changes in populations of colon microorganisms, viz. lactobacilli, bifidobacteria, clostridia, fecal coliforms and total anaerobes, after feeding and fermentation with different treatments of low-fat ice cream. The ice cream samples were either administered pure, supplemented with B. lactis Bb-12, KMN or both. Metabolic products of microfloral fermentation, including SCFA (acetic, propionic, and butyric acids), lactic acid, ammonia and biogenic amines (cadaverine, putrescine, methylamine and tyramine) were also assessed within this study.

\section{Materials and methods}

\subsection{Probiotic culture and chemicals}

Lyophilized B. lactis Bb-12 was obtained from Chr. Hansen (Hørsholm, Denmark). Absolute ethanol, Lcysteine hydrochloride, sodium hydroxide (bacterial grade),hydrochloric acid (conc.), sodium hydroxide, $D$ $(+)$-glucose, mucin from bovine submaxillary gland, phosphate buffer saline, boric acid, sodium hydroxide, bicarbonate, tryptose sulfite cycloserine (TSC) agar, Clostridium perfringens selective supplement, Tris (hydroxymethyl) aminomethane, sodium acetate, magnesium oxide, ammonia and acetic acid were purchased from Merck (Darmstadt, Germany). Sodium thioglycolate, sulfuric acid, xylan, arabinogalactan, $L$ cysteine, sodium thioglycolate, sodium hydrogen carbonate, pancreatin from porcine pancreas, ethylenediaminetetraacetic acid (EDTA), trichloroacetic acid (TCA), dansyl chloride and acetonitrile were supplied from Sigma-Aldrich (St. Louis, MO, USA). de Man, Rogosa and Sharpe (MRS) broth, MacConkey agar, yeast extract and peptone water were purchased from Hi-Media (Mumbai, India). Oxgall, brain heart infusion (BHI) agar and polyacrylamide gels were procured from Difco ${ }^{\mathrm{TM}}$ (BD, USA), Oxoid (Hampshire, United Kingdom) and Bio-Rad Laboratories Pty., Ltd. (Gladesville, New South Wales, Australia), respectively.

\subsection{Extraction of Krueo Ma Noy gum}

Krueo Ma Noy leaves were harvested from an orchard in Sakon Nakhon province, Thailand. The washed leaves were sun-dried for $15 \mathrm{hrs}$ before blending. The blended leaves were extracted with distilled water at a ratio of $1: 20(\mathrm{w} / \mathrm{v})$ at $75^{\circ} \mathrm{C}$ for $1 \mathrm{hr}$ (Singthong et al., 2005). The extract was then filtered and precipitated with absolute ethanol at a ratio of $1: 3(\mathrm{v} / \mathrm{v})$. Afterward, the precipitate was dried using a vacuum oven (XF050, France Etuves, Chelles, France) and powdered using a blender (National, Bangkok, Thailand)

\subsection{Preparation of probiotic pellet}

Lyophilized B. lactis $\mathrm{Bb}-12$ was incubated in sterile MRS broth containing $0.05 \% \quad(\mathrm{w} / \mathrm{v}) \quad L$-cysteine hydrochloride at $37^{\circ} \mathrm{C}$ for $20 \mathrm{hrs}$ and then harvested by 
centrifugation (Rotina 46R Centrifuge, Hettich ${ }^{\circledR}$, Tuttlingen, Germany) with a rotary speed of 4,500 rpm at $4{ }^{\circ} \mathrm{C}$ for 20 mins. Afterward, the precipitated cells were washed twice with $0.85 \%(\mathrm{w} / \mathrm{v})$ sterile saline water and kept in a refrigerator at $4^{\circ} \mathrm{C}$ for $16 \mathrm{hrs}$ (overnight). For activation, the pellet cells were warmed at $37^{\circ} \mathrm{C}$ for $1 \mathrm{hrs}$ before supplementation into low-fat ice cream.

\subsection{Production of low-fat ice cream}

To produce low-fat ice cream, $76 \% \quad(\mathrm{w} / \mathrm{w})$ pasteurized skim milk plus $2 \%(\mathrm{w} / \mathrm{w})$ milk butter were heated at $50^{\circ} \mathrm{C}$ for $5 \mathrm{mins}$ before mixing with other solid ingredients, including $8 \%(\mathrm{w} / \mathrm{w})$ skim milk powder, $12 \%$ $(\mathrm{w} / \mathrm{w})$ sucrose, $1 \%(\mathrm{w} / \mathrm{w})$ corn starch and $1 \%(\mathrm{w} / \mathrm{w})$ gelatin $(240$ Bloom) or $0.5 \%(\mathrm{w} / \mathrm{w})$ gelatin plus $0.5 \%(\mathrm{w} /$ w) KMN (Section 2.1). The mixture was blended for 2 mins, pasteurized at $85^{\circ} \mathrm{C}$ for 5 mins and then incubated in a refrigerator at $4^{\circ} \mathrm{C}$ for $16 \mathrm{hrs}$ (overnight). Subsequently, $1 \%(\mathrm{w} / \mathrm{w})$ precipitated cells (Section 2.2 ) were added into the incubated mixture, with $B$. lactis $\mathrm{Bb}$ 12 roughly $10^{14} \mathrm{CFU} / \mathrm{g}$, and the ice cream was made using an ice cream maker (National). Later, the ice cream sample was placed into $50 \mathrm{ml}$ plastic cup and frozen at $-25^{\circ} \mathrm{C}$ overnight for hardening (Chaikham and Rattasena, 2017).

\subsection{Gut model experiment}

Basal nutrient medium and pancreatic solution were prepared (Table 1) and sterilized at $121^{\circ} \mathrm{C}$ for 15 mins. The basal nutrient medium was acidified with $37 \%$ (conc.) hydrochloric acid to $\mathrm{pH} 2$. The acidified basal nutrient medium and pancreatic solution were then used for feeding into the dynamic gut model with $1 \mathrm{ml} / \mathrm{min}$ flow rate. Four sterile fermentation vessels which consisted of the stomach $\left(1^{\text {st }}\right.$ vessel $)$, small intestine $\left(2^{\text {nd }}\right.$ vessel), proximal colon ( $3^{\text {rd }}$ vessel) and distal colon $\left(4^{\text {th }}\right.$ vessel) were set up and operated according to the running-setup protocol of Chaikham et al. (2012) with some modifications. The system temperature was set at $37^{\circ} \mathrm{C}$, by means of a circulating water bath, and culture $\mathrm{pH}$ was maintained at 5.6-5.9 and 6.6-6.9 in proximal and distal colon vessels using a $\mathrm{pH}$ controller with the automated addition of $0.25 \mathrm{M}$ hydrochloric acid and 0.1 $\mathrm{M}$ sodium hydroxide. Each colon vessel was inoculated with $30 \mathrm{~mL}$ of fecal slurry from five healthy donors which were prepared using pre-reduced $0.1 \mathrm{M}$ phosphate buffer saline $(\mathrm{pH} 7)$ plus $2 \mathrm{~g}$ of sodium thioglycolate (reducing agent) and then mixed in a stomacher for 5 mins. Fecal samples were obtained from three male and two female volunteers with a mean age of 25 years who had not taken antibiotics for at least 6 months prior to providing the sample and had no history of a gastrointestinal disorder. Various treatment compositions were fed continuously into the model for 9 weeks, as shown in Table 2. The basal period (2 weeks) was intended to modulate the microbiome in the different colons to the prevailing conditions in order to obtain a population that resembles the in vivo situation in terms of either community composition or metabolic activity (Chaikham et al., 2016). For collecting the fermented samples in both colon vessels, after 2 days feeding, 20 $\mathrm{mL}$ of colon fluids were withdrawn daily for assessments of microflora metabolites and populations.

2.6 Determinations of short-chain fatty acids and lactic acid

A $1-\mathrm{mL}$ colon fluid was centrifuged with the rotary speed of $4,500 \mathrm{rpm}$ at $4^{\circ} \mathrm{C}$ for $15 \mathrm{mins}$ and then the supernatant was filtered through a $0.20-\mu \mathrm{m}$ nylon filter (Vertical, Bangkok, Thailand). Afterward, $20 \mu \mathrm{L}$ of filtrate was injected onto an HPLC system (Lachrom, Poole, United Kingdom) equipped with a refractive index detector (Lachrom L-7490) and an automatic injector (Lachrom L-7200). The column used was a RezexROA-Organic Acid-H+ column $(300 \times 7.80 \mathrm{~mm}$, Phenomenex, Cheshire, United Kingdom). The column

Table 1. Medium compositions for in vitro experimental feeding.

\begin{tabular}{ll}
\hline Media & Amounts of substances in 1 L distilled water \\
\hline \multirow{2}{*}{ Feeding medium } & $\begin{array}{l}1 \mathrm{~g} \text { arabinogalactan, } 2 \mathrm{~g} \text { pectin, } 1 \mathrm{~g} \text { xylan, } 3 \mathrm{~g} \text { potato starch, } 0.4 \mathrm{~g} D(+) \text {-glucose, } 3 \mathrm{~g} \text { yeast extract, } 1 \mathrm{~g} \\
\text { peptone water, } 4 \mathrm{~g} \text { mucin from bovine submaxillary gland, } 0.5 \mathrm{~g} \text { of } L \text {-cysteine and distill water }\end{array}$ \\
Pancreatic solution & $12 \mathrm{~g}$ Oxgall, $25 \mathrm{~g}$ sodium hydrogen carbonate, $1.8 \mathrm{~g}$ pancreatin from porcine pancreas and distilled water \\
\hline
\end{tabular}

Table 2. Differences in feeding compositions of low-fat ice cream.

\begin{tabular}{ll}
\hline Experimental running & Feeding compositions \\
\hline Basal (14 days) & $150 \mathrm{ml}$ basal nutrient medium \\
Treatment 1 (7 days) & $150 \mathrm{ml}$ basal nutrient medium $+50 \mathrm{~g}$ low-fat ice cream (1\% gelatin) \\
Washout 1 (7 days) & $150 \mathrm{ml}$ basal nutrient medium \\
Treatment 2 (7 days) & $150 \mathrm{ml}$ basal nutrient medium $+50 \mathrm{~g}$ low-fat ice cream $(1 \%$ gelatin $)+$ B. lactis Bb-12 $\left(\sim 10^{14} \mathrm{CFU} / \mathrm{g}\right)$ \\
Washout 2 (7 days) & $150 \mathrm{ml}$ basal nutrient medium \\
Treatment 3 (7 days) & $150 \mathrm{ml}$ basal nutrient medium $+50 \mathrm{~g}$ low-fat ice cream $(0.5 \%$ gelatin and $0.5 \% \mathrm{KMN})$ \\
Washout 3 (7 days) & $150 \mathrm{ml}$ basal nutrient medium \\
Treatment 4 (7 days) & $150 \mathrm{ml}$ basal nutrient medium $+50 \mathrm{~g}$ low-fat ice cream $(0.5 \%$ gelatin and $0.5 \% \mathrm{KMN})+$ B. lactis Bb- \\
\hline
\end{tabular}


was then left in the oven at $84^{\circ} \mathrm{C}$ and $0.0025 \mathrm{mM}$ sulfuric acid was used as a mobile phase at a flow rate of $0.5 \mathrm{~mL} / \mathrm{min}$. Data were acquired using JCL6000 software (Jones Chromatography, Wales, United Kingdom) and quantification of the samples was carried out using calibration curves of acetic, propionic, butyric and lactic acids.

\subsection{Investigation of colon microflora diversities}

Briefly, the colon fluids were appropriately diluted with $0.1(\mathrm{w} / \mathrm{v})$ sterile peptone water and spread-plated on five selective media as follows: RB-agar for bifidobacteria (anaerobic environment, $37^{\circ} \mathrm{C}, 96 \mathrm{hrs}$ ), LAMVAB agar for lactobacilli (anaerobic environment, $37^{\circ} \mathrm{C}, 72 \mathrm{hrs}$ ), MacConkey agar for fecal coliforms (aerobic environment, $42^{\circ} \mathrm{C}, 24 \mathrm{hrs}$ ), TSC agar plus $C$. perfringens selective supplement for clostridia (anaerobic environment, $37^{\circ} \mathrm{C}, 24 \mathrm{hrs}$ ) and $\mathrm{BHI}$ agar for total anaerobes (anaerobic environment, $37^{\circ} \mathrm{C}, 24 \mathrm{hrs}$ ). Later, all plated media were incubated under different conditions before colony counting (Chaikham et al., 2012).

Polymerase chain reaction-denaturing gradient gel electrophoresis (PCR-DGGE) patterns of general colon bacteria were analyzed following the modified protocol of Chaikham et al. (2012). Accordingly, PCR fragments were loaded onto $8 \%(\mathrm{w} / \mathrm{v})$ polyacrylamide gels in $1 \times$ TAE buffer solution $[\mathrm{pH} \quad 7.4 ; 20$ mMTris (hydroxymethyl) aminomethane, $10 \mathrm{mM}$ sodium acetate and $0.5 \mathrm{mM}$ EDTA]. PCR-DGGE fingerprints were made using a Bio-Rad D Gene System (Bio-Rad Laboratories Pty., Ltd., Gladesville, New South Wales, Australia) with a denaturant gradient between $45 \%$ to $60 \%$. Different DNA patterns and densities were grouped and calculated using a BioNumerics software v.2.0 (Applied Maths, Sint-Martens-Latem, Belgium).

\subsection{Determinations of ammonia and biogenic amines}

Ammonia concentration in colon fluids was determined according to the method as described by Chaikham et al. (2012). A 1-mL colon fluid was added with one teaspoon of magnesium oxide and the mixture was then distilled using a Kjeldahl Apparatus Vapodest 30 S (Gerhardt, Königswinter, Germany). The released ammonia gas was entrapped with boric acid solution before titration with $0.02 \mathrm{M}$ hydrochloric acid. The ammonia concentration was calculated and expressed as gram ammonia per $1 \mathrm{~L}$ colon fluid $(\mathrm{g} / \mathrm{L})$.

Cadaverine, putrescine, methylamine and tyramine were determined using the modified HPLC method as described by Tosukhowong et al. (2011). A total of five milliliters of colon fluids were well-mixed with $35 \mathrm{~mL}$ of $10 \%$ TCA solution before centrifugation at $4,000 \mathrm{rpm}$ for
15 mins. One milliliter supernatant was mixed with 0.2 $\mathrm{mL}$ of $2 \mathrm{M}$ sodium hydroxide and $0.3 \mathrm{~mL}$ of saturated sodium bicarbonate and then allowed to stand at room temperature for 30 mins. A $2 \mathrm{~mL}$ of $10 \mathrm{mg} / \mathrm{mL}$ dansyl chloride solution was added into the mixture before incubation at $40^{\circ} \mathrm{C}$ for 30 mins. After that, $0.1 \mu \mathrm{L}$ of $25 \%$ ammonia was added to stop the reaction and centrifuged at 4,000 rpm for 10 mins. The supernatant was filtered through a $0.20-\mu \mathrm{m}$ nylon membrane filter and $20 \mu \mathrm{L}$ filtrate was injected into a Shimadzu HPLC system (CL-10 ADVP, Shimadzu, Kyoto, Japan). Separation of biogenic amines was achieved using a C18 column (YMC-Pack ODS-AM, $5 \mu \mathrm{m}, 4.6 \mathrm{~mm}$ ID $\times 250$ $\mathrm{mm}$; YMC, Kyoto Japan). The mobile phase was a mixture of $0.1 \%$ acetic acid (solvent $\mathrm{A}$ ) and $0.1 \%$ acetic acid in acetonitrile (solvent B) with a flow rate of 1.0 $\mathrm{mL} / \mathrm{min}$. The gradient system of the mobile phase commenced from $0 \mathrm{~min}(50 \% \mathrm{~A}$ and $50 \% \mathrm{~B})$ to $30 \mathrm{mins}$ $(10 \% \mathrm{~A}$ and $90 \% \mathrm{~B}), 10$ mins $(50 \% \mathrm{~A}$ and $50 \% \mathrm{~B})$ and maintained at this state to 10 mins. The temperature of the column was set at $40^{\circ} \mathrm{C}$ and UV detection was at 254 $\mathrm{nm}$. The peak area of each component was determined and converted to concentration.

\subsection{Statistical analysis}

Five replicates were performed, and the mean value was calculated. Analysis of variance (ANOVA) was used to carry out the variation and significance of difference. Determination of significant differences within treatment means was done using Duncan's multiple range tests at 95\%. Pearson correlation coefficient was used for grouping the DNA patterns on PCR-DGGE fingerprints.

\section{Results and discussion}

\subsection{Short-chain fatty acids and lactic acid}

The results in Table 3 showed the concentrations of acetic acid, propionic acid, butyric acid, total SCFA and lactic acid presented in proximal and distal colon vessels following treatments of basal nutrient medium (Table 1) along with low-fat ice cream, $B$. lactis Bb-12, KMN and combination with both $B$. lactis $\mathrm{Bb}-12$ and $\mathrm{KMN}$ (Table $2)$. The gut model was left for long-term running with periodical washouts following 7 days of different treatments, as can be observed from Table 2. Regarding SCFA, it was noticed that acetic acid concentrations were of the highest levels compared to propionic and butyric acids in both colon vessels $(P \leq 0.05)$. This complied to the population data from various studies showing the greatest acetic acid production among the three types of SCFA, where ratios of acetic, propionic and butyric acids production in large intestinal follow an approximate ratio of 3:1:1 (Topping and Clifton, 2001). Probiotic-low-fat ice cream (Treatment 2) also 
Table 3. Quantities of short-chain fatty acids and lactic acid in colon vessels after supplementation with difference treatments of low-fat ice cream.

\begin{tabular}{|c|c|c|c|c|c|c|c|c|}
\hline \multirow[b]{2}{*}{$\begin{array}{c}\text { Metabolites } \\
(\mathrm{g} / \mathrm{L})\end{array}$} & \multicolumn{8}{|c|}{ Experimental periods } \\
\hline & Basal & $\begin{array}{c}\text { Treatment } \\
1\end{array}$ & Washout 1 & $\begin{array}{c}\text { Treatment } \\
2\end{array}$ & Washout 2 & $\begin{array}{c}\text { Treatment } \\
3\end{array}$ & Washout 3 & $\begin{array}{c}\text { Treatment } \\
4\end{array}$ \\
\hline \multicolumn{9}{|l|}{ Proximal colon } \\
\hline Acetic acid & $\begin{array}{c}0.63 \pm \\
0.08^{\mathrm{CDf}}\end{array}$ & $\begin{array}{c}1.29 \pm \\
0.09^{\mathrm{CDc}}\end{array}$ & $\begin{array}{l}0.92 \pm \\
0.10^{\mathrm{Bc}}\end{array}$ & $\begin{array}{c}1.37 \pm \\
0.14^{\mathrm{CDbc}}\end{array}$ & $\begin{array}{l}1.10 \pm \\
0.05^{\mathrm{Dd}}\end{array}$ & $\begin{array}{c}1.57 \pm \\
0.14^{\mathrm{CDb}}\end{array}$ & $\begin{array}{l}1.13 \pm \\
0.04^{\mathrm{Dd}}\end{array}$ & $\begin{array}{l}1.83 \pm \\
0.10^{\mathrm{Da}}\end{array}$ \\
\hline Propionic acid & $\begin{array}{l}0.34 \pm \\
0.04^{\mathrm{Fe}}\end{array}$ & $\begin{array}{c}0.58 \pm \\
0.07^{\text {EFcd }}\end{array}$ & $\begin{array}{l}0.45 \pm \\
0.06^{\mathrm{Cd}}\end{array}$ & $\begin{array}{c}0.70 \pm \\
0.11^{\mathrm{EFbc}}\end{array}$ & $\begin{array}{l}0.54 \pm \\
0.03^{\mathrm{Ed}}\end{array}$ & $\begin{array}{l}0.84 \pm \\
0.05^{\mathrm{Eb}}\end{array}$ & $\begin{array}{c}0.50 \pm \\
0.08^{\mathrm{EFd}}\end{array}$ & $\begin{array}{l}0.97 \pm \\
0.05^{\mathrm{Fa}}\end{array}$ \\
\hline Butyric acid & $\begin{array}{l}0.29 \pm \\
0.06^{\mathrm{Fe}}\end{array}$ & $\begin{array}{l}0.47 \pm \\
0.05^{\text {Fcd }}\end{array}$ & $\begin{array}{l}0.41 \pm \\
0.07^{\mathrm{Cd}}\end{array}$ & $\begin{array}{l}0.72 \pm \\
0.03^{\mathrm{Fb}}\end{array}$ & $\begin{array}{l}0.60 \pm \\
0.08^{\text {Fcd }}\end{array}$ & $\begin{array}{l}0.75 \pm \\
0.02^{\mathrm{Fb}}\end{array}$ & $\begin{array}{l}0.52 \pm \\
0.03^{\mathrm{Fc}}\end{array}$ & $\begin{array}{l}0.90 \pm \\
0.04^{\mathrm{Fa}}\end{array}$ \\
\hline Total SCFA & $\begin{array}{l}1.35 \pm \\
0.04^{\mathrm{Bg}}\end{array}$ & $\begin{array}{l}2.57 \pm \\
0.12^{\mathrm{Bd}}\end{array}$ & $\begin{array}{l}1.91 \pm \\
0.10^{\mathrm{Af}}\end{array}$ & $\begin{array}{l}2.97 \pm \\
0.12^{\mathrm{Bc}}\end{array}$ & $\begin{array}{l}2.43 \pm \\
0.07^{\mathrm{Bd}}\end{array}$ & $\begin{array}{l}3.36 \pm \\
0.09^{\mathrm{Bb}}\end{array}$ & $\begin{array}{l}2.27 \pm \\
0.08^{\mathrm{Be}}\end{array}$ & $\begin{array}{l}3.89 \pm \\
0.13^{\mathrm{Ba}}\end{array}$ \\
\hline Lactic acid & $\begin{array}{l}0.54 \pm \\
0.10^{\mathrm{Df}}\end{array}$ & $\begin{array}{c}1.15 \pm \\
0.07^{\text {Dcd }}\end{array}$ & $\begin{array}{l}0.83 \pm \\
0.08^{\mathrm{Be}}\end{array}$ & $\begin{array}{c}1.23 \pm \\
0.05^{\mathrm{Dbc}}\end{array}$ & $\begin{array}{l}0.81 \pm \\
0.10^{\mathrm{Ee}}\end{array}$ & $\begin{array}{l}1.30 \pm \\
0.17^{\mathrm{Db}}\end{array}$ & $\begin{array}{l}0.98 \pm \\
0.11^{\text {Dde }}\end{array}$ & $\begin{array}{l}1.74 \pm \\
0.16^{\mathrm{Da}}\end{array}$ \\
\hline \multicolumn{9}{|l|}{ Distal colon } \\
\hline Acetic acid & $\begin{array}{l}0.72 \pm \\
0.06^{\mathrm{Cf}}\end{array}$ & $\begin{array}{l}1.46 \pm \\
0.12^{\mathrm{Ccd}}\end{array}$ & $\begin{array}{l}0.87 \pm \\
0.09^{\mathrm{Be}}\end{array}$ & $\begin{array}{l}1.53 \pm \\
0.14^{\mathrm{Cc}}\end{array}$ & $\begin{array}{l}1.35 \pm \\
0.10^{\mathrm{Cd}}\end{array}$ & $\begin{array}{l}1.78 \pm \\
0.11^{\mathrm{Cb}}\end{array}$ & $\begin{array}{l}1.28 \pm \\
0.09^{\mathrm{Cd}}\end{array}$ & $\begin{array}{l}2.10 \pm \\
0.16^{\mathrm{Ca}}\end{array}$ \\
\hline Propionic acid & $\begin{array}{l}0.40 \pm \\
0.01^{\mathrm{Ee}}\end{array}$ & $\begin{array}{l}0.71 \pm \\
0.08^{\mathrm{Ec}}\end{array}$ & $\begin{array}{l}0.50 \pm \\
0.04^{\mathrm{Cd}}\end{array}$ & $\begin{array}{c}0.82 \pm \\
0.09^{\mathrm{EFbc}}\end{array}$ & $\begin{array}{l}0.58 \pm \\
0.05^{\mathrm{Fd}}\end{array}$ & $\begin{array}{l}0.92 \pm \\
0.08^{\mathrm{Eb}}\end{array}$ & $\begin{array}{c}0.57 \pm \\
0.09^{\mathrm{EFd}}\end{array}$ & $\begin{array}{l}1.17 \pm \\
0.10^{\mathrm{Ea}}\end{array}$ \\
\hline Butyric acid & $\begin{array}{c}0.37 \pm \\
0.03^{\mathrm{EFe}}\end{array}$ & $\begin{array}{c}0.58 \pm \\
0.08^{\mathrm{EFcd}}\end{array}$ & $\begin{array}{l}0.49 \pm \\
0.06^{\mathrm{Cd}}\end{array}$ & $\begin{array}{l}0.85 \pm \\
0.07^{\mathrm{Eb}}\end{array}$ & $\begin{array}{l}0.56 \pm \\
0.07^{\text {Fcd }}\end{array}$ & $\begin{array}{l}0.91 \pm \\
0.07^{\mathrm{Eb}}\end{array}$ & $\begin{array}{l}0.60 \pm \\
0.02^{\mathrm{Ec}}\end{array}$ & $\begin{array}{l}1.25 \pm \\
0.08^{\mathrm{Ea}}\end{array}$ \\
\hline Total SCFA & $\begin{array}{l}1.55 \pm \\
0.07^{\mathrm{Ag}}\end{array}$ & $\begin{array}{l}2.94 \pm \\
0.14^{\mathrm{Ad}}\end{array}$ & $\begin{array}{l}1.95 \pm \\
0.11^{\mathrm{Af}}\end{array}$ & $\begin{array}{l}3.36 \pm \\
0.08^{\mathrm{Ac}}\end{array}$ & $\begin{array}{l}2.64 \pm \\
0.12^{\mathrm{Ae}}\end{array}$ & $\begin{array}{l}3.80 \pm \\
0.13^{\mathrm{Ab}}\end{array}$ & $\begin{array}{l}2.61 \pm \\
0.10^{\mathrm{Ae}}\end{array}$ & $\begin{array}{l}4.73 \pm \\
0.15^{\mathrm{Aa}}\end{array}$ \\
\hline Lactic acid & $\begin{array}{c}0.69 \pm \\
0.12^{\mathrm{CDd}}\end{array}$ & $\begin{array}{l}1.39 \pm \\
0.10^{\mathrm{Cb}}\end{array}$ & $\begin{array}{c}0.90 \pm \\
0.15^{\text {Bcd }}\end{array}$ & $\begin{array}{l}1.45^{ \pm} \\
0.09^{\mathrm{Cb}}\end{array}$ & $\begin{array}{l}0.85 \pm \\
0.08^{\text {Ecd }}\end{array}$ & $\begin{array}{l}1.49 \pm \\
0.15^{\mathrm{Db}}\end{array}$ & $\begin{array}{l}1.02 \pm \\
0.08^{\mathrm{Dc}}\end{array}$ & $\begin{array}{c}1.95 \pm \\
0.13^{\mathrm{CDa}}\end{array}$ \\
\hline
\end{tabular}

Values are expressed as mean values \pm standard deviation $(n=5)$. Means in the same rows with the same lowercase letters and means in the same columns with the same uppercase letters indicate no significant difference $(P>0.05)$.

significantly increased $(P \leq 0.05)$ the levels of all SCFA compared to pure low-fat ice cream (Treatment 1). Similarly, in the study of Chaikham and Rattanasena (2017) on the effect of low-fat ice cream supplementation with probiotics (Lactobacillus casei 01 and Lactobacillus acidophilus LA5) on human colonic microflora communities, probiotic along with low-fat ice cream was shown to boost the production of SCFA, as demonstrated by the increase of all SCFA (acetate, butyrate and propionate) in both proximal and distal colon vessels of the human colon simulator compared to pure low-fat ice cream. However, the concentration of total SCFA was significantly higher $(P \leq 0.05)$ in the presence of low-fat ice cream plus KMN (Treatment 3) during fermentation, expressed as $3.36 \pm 0.09$ and $3.80 \pm 0.13 \mathrm{~g} / \mathrm{L}$ in respective proximal and distal colon vessels, when compared to treatments of low-fat ice cream alone and the latter in combination with $B$. lactis Bb-12.

In this case, the simulated colon treatment incorporating the addition of $B$. lactis $\mathrm{Bb}-12$ supplemented low-fat ice cream together with KMN (Treatment 4), was proven to be the treatment combination that can most effectively modulate the composition of all SCFA studied in this research $(P \leq 0.05)$. A significant increase in SCFA concentrations was established in proximal and distal colon vessels, of $3.89 \pm 0.13$ and $4.73 \pm 0.15 \mathrm{~g} / \mathrm{L}$, respectively, compared to probiotic-low-fat ice cream, low-fat ice cream with KMN and pure low-fat ice cream. There was currently insufficient research on the synergistic effects of KMN on the human colon microbiome, many dietary fibers, including pectin, have been used as prebiotics to deliver beneficiary effects to alter the gut microbial population and improve host health (Woods and Gorbach, 2001). Pectin is readily soluble in water and initiates gel formation within the gastrointestinal tract, enhancing gut microflora fermentation processes. Gel matrices increase the surface area available for enzymatic reactions and bacteria-mediated degradation processes of undigested food substances (Gibson, 2004). SCFA formed through food and nutrient fermentation by the gut microbiota confer numerous health benefits to the host. SCFA serve as nutrients for colonic epithelium, modulators of $\mathrm{pH}$ within intracellular and colon environments, regulators of cell volume and as enhancers of metabolic processes, such as ion transport, cell proliferation and mineral absorption (Cook and Sellin, 1998). There are a number of scientific evidence supporting the roles of SCFA as major regulators of colonic health and are known to exhibit preventative effects against gastrointestinal disorders, cancer, anti-cardiovascular diseases and suppress pathogen growth (Van Immerseel et al., 2010; den Besten et al., 2013).

Here, the impact of various treatments on lactic acid concentration in the human gut reactor was observed in 
Table 3. While the control treatment (basal period) contained lowest concentrations of $0.54 \pm 0.10$ and $0.69 \pm 0.12 \mathrm{~g} / \mathrm{L}$ lactic acid in both proximal and distal colon vessels, respectively, all treatments in the presence of low-fat ice cream demonstrated a significant increase in lactic acid in both compartments $(P \leq 0.05)$. Noticeably, while lactic acid concentrations increased with treatments of low-fat ice cream with $B$. lactis $\mathrm{Bb}$ 12 , and of low-fat ice cream with $\mathrm{KMN}$, the greatest increase in concentrations of lactic acid observed in both reactor vessels were accounted by treatments of low-fat ice cream in combination with $B$. lactis $\mathrm{Bb}-12$ and $\mathrm{KMN}$, which were $1.74 \pm 0.16 \mathrm{~g} / \mathrm{L}$ in proximal colon and $1.95 \pm 0.13 \mathrm{~g} / \mathrm{L}$ in distal colon. Some of the factors contributing to higher levels of lactic acid can be accounted by the ingredients of low-fat ice cream, including sucrose and cornstarch, which served as carbohydrate substrates of colon microbiota metabolism, fermentation, and increased synthesis of lactic acid and SCFA. It is known that lactic acid is one of the major end-products of Bifidobacterium fermentation, along with other strains of genera Lactobacillus (Biavati, 2001; Pokusaeva et al., 2011). Thus, the inoculation of probiotics allows for increased substrate utilization to increase the yields such organic acids (Chaikham et al., 2012; Chaikham and Apichartsrangkoon, 2014; Chaikham and Rattanasena, 2017). Although little research has been conducted on the prebiotic properties of $\mathrm{KMN}$, results suggested increased metabolic byproduct yields of the simulated gut model in its presence. The presence of pectin in KMN may have contributed to this effect.

Comparing the levels of SCFA and lactic acid within the two colon compartments, the concentrations of all organic acids were significantly higher $(P \leq 0.05)$ for all treatment compositions in the distal colon compared to the proximal colon. Overall, a more significant rise in levels was observed for SCFA as opposed to lactic acid. These results suggested the presence of unabsorbed organic acids, as digestion of the treatments proceed from simulated proximal (ascending and transverse) to distal (descending) colons (Chaikham et al., 2012). Similar trends of increase in acetate, butyrate, propionate and branched acid levels in ascending, transverse and descending colon compartments could be observed in the report of Van de Wiele et al. (2006) on in vitro prebiotic effects of longer-degree polymerized inulin-type fructans. In healthy humans, the production rate of SCFA in the proximal colon was higher than that of the distal colon due to high substrate concentration. However, the SCFA in the distal colon was higher than that of the proximal colon due to the accumulation of SCFA in the colon (MacFarlane et al., 1992). Subsequent depletion is defined by lower levels of SCFA production, from $\sim 250$
$\mathrm{mM}$ SCFA $/ \mathrm{kg}$ fecal $/ 48 \mathrm{hrs}$ in the proximal colon to $\sim 50$ $\mathrm{mM}$ SCFA $/ \mathrm{kg}$ fecal $/ 48 \mathrm{hrs}$ in the distal colon (MacFarlane and Gibson, 1995). While fermentation is predominant in the human proximal colon, trace amounts $(\sim 5 \%)$ of SCFA unabsorbed by colonocytes are transported and deposited along distal regions, and ultimately expelled via fecal matter excretion (Topping and Clifton, 2001).

\subsection{Colon microbial populations and PCR-DGCE fingerprints}

Enumeration and subsequent colony count determinations of specific bacterial strains and total anaerobes were conducted to observe the changes in in vitro gut microbial compositions under varied treatment compositions of low-fat ice cream, washout period and basal conditions. The colony units were expressed in terms of $\log \mathrm{CFU} / \mathrm{mL}$ colon fluid, as can be observed from Table 4. Compared to basal microbial concentrations, it was found that all treatments of low-fat ice cream (Treatments 2, 3 and 4) in both colon vessels significantly increased $(P \leq 0.05)$ levels of colonic lactobacilli by approximately 1.3 $-1.9 \log \quad \mathrm{CFU} / \mathrm{mL}$ (proximal colon) and $\sim 1.0-1.8 \log \mathrm{CFU} / \mathrm{ml}$ (distal colon), and of bifidobacteria by $\sim 1.3-2.4 \log \mathrm{CFU} / \mathrm{mL}$ (proximal colon) and $\sim 1.0-2.0 \log \mathrm{CFU} / \mathrm{mL}$ (distal colon) as compared to basal treatment (Treatment 1). According to Chaikham and Rattanasena (2017), ingredients of ice cream provide carbon and nitrogen sources, whereas probiotic inoculation increases the utilization capacity of those aforementioned fermentation substrates.

Although supplementation of low-fat ice cream with B. lactis $\mathrm{Bb}-12, \mathrm{KMN}$ and both in combination significantly increased $(P \leq 0.05)$ lactobacilli prevalence in the gut reactor compared to pure low-fat ice cream, there was no significant difference $(P>0.05)$ in the quantities of lactobacilli among the supplementation with probiotic or KMN on their own within the proximal colon compartment ( 7.9-8.0 log CFU/ml). In the distal colon vessel, however, significant increases were primarily observed in treatments containing $B$. lactis $\mathrm{Bb}-$ 12 (Treatments 2 and 4). Combined supplementation of low-fat ice cream, probiotic and KMN yielded the highest distal colon population of beneficial lactobacilli $(8.24 \pm 0.10 \log \mathrm{CFU} / \mathrm{ml})$. Similar trends were also observed for bifidobacteria levels in both vessels, which can be accounted for by direct inoculation of $B$. lactis $\mathrm{Bb}$ -12 in the basal nutrient medium. The greater prevalence of lactobacilli and bifidobacteria suggested synergistic effects of $B$. lactis $\mathrm{Bb}-12$, and potential prebiotic effects of $\mathrm{KMN}$ on the growth of beneficial colon bacteria. Similarly, a study by Bianchi et al. (2014) showed 
Table 4. Microflora communities in colon vessels after supplementation with difference treatments of low-fat ice cream.

\begin{tabular}{|c|c|c|c|c|c|c|c|c|}
\hline \multirow{2}{*}{$\begin{array}{l}\text { Microbiome } \\
(\log \text { CFU/ml) }\end{array}$} & \multicolumn{8}{|c|}{ Experimental periods } \\
\hline & Basal & $\begin{array}{c}\text { Treatment } \\
1\end{array}$ & Washout 1 & $\begin{array}{c}\text { Treatment } \\
2\end{array}$ & Washout 2 & $\begin{array}{c}\text { Treatment } \\
3\end{array}$ & Washout 3 & $\begin{array}{c}\text { Treatment } \\
4\end{array}$ \\
\hline \multicolumn{9}{|l|}{ Proximal colon } \\
\hline \multirow{2}{*}{ Bifidobacteria } & $6.47 \pm$ & $7.75 \pm$ & $7.13 \pm$ & $8.60 \pm$ & $7.15 \pm$ & $8.13 \pm$ & $7.20 \pm$ & $8.90 \pm$ \\
\hline & $0.07^{\mathrm{Ff}}$ & $0.11^{\mathrm{Ac}}$ & $0.04^{\mathrm{Ce}}$ & $0.12^{\mathrm{Ba}}$ & $0.09^{\text {Ede }}$ & $0.11^{\mathrm{Bb}}$ & $0.03^{\mathrm{Ed}}$ & $0.28^{\mathrm{Aa}}$ \\
\hline \multirow{2}{*}{ Lactobacilli } & $6.15 \pm$ & $7.40 \pm$ & $6.74 \pm$ & $7.92 \pm$ & $6.81 \pm$ & $7.90 \pm$ & $6.75 \pm$ & $8.01 \pm$ \\
\hline & $0.08^{\mathrm{Gd}}$ & $0.07^{\mathrm{BCb}}$ & $0.05^{\mathrm{Ec}}$ & $0.06^{\mathrm{Ca}}$ & $0.10^{\mathrm{Fc}}$ & $0.06^{\mathrm{Ca}}$ & $0.15^{\mathrm{Fc}}$ & $0.17^{\mathrm{Ba}}$ \\
\hline Fecal & $7.89 \pm$ & $6.76 \pm$ & $8.03 \pm$ & $6.50 \pm$ & $7.95 \pm$ & $6.53 \pm$ & $7.82 \pm$ & $6.18 \pm$ \\
\hline coliforms & $0.10^{\mathrm{Ca}}$ & $0.09^{\mathrm{Eb}}$ & $0.12^{\mathrm{Ba}}$ & $0.05^{\mathrm{Gc}}$ & $0.03^{\mathrm{Ba}}$ & $0.04^{\mathrm{Gc}}$ & $0.10^{\mathrm{Ba}}$ & $0.04^{\mathrm{Ed}}$ \\
\hline \multirow{2}{*}{ Clostridia } & $7.50 \pm$ & $7.14 \pm$ & $7.95 \pm$ & $6.95 \pm$ & $7.86 \pm$ & $6.90 \pm$ & $7.85 \pm$ & $6.27 \pm$ \\
\hline & $0.05^{\mathrm{Db}}$ & $0.12^{\mathrm{Dc}}$ & $0.09^{\mathrm{Ba}}$ & $0.10^{\mathrm{Fcd}}$ & $0.04^{\mathrm{Ca}}$ & $0.08^{\mathrm{Fd}}$ & $0.05^{\mathrm{Ba}}$ & $0.13^{\mathrm{Ee}}$ \\
\hline Total & $8.14 \pm$ & $7.62 \pm$ & $8.45 \pm$ & $7.43 \pm$ & $8.20 \pm$ & $7.59 \pm$ & $8.30 \pm$ & $6.99 \pm$ \\
\hline anaerobes & $0.07^{\mathrm{Bb}}$ & $0.20^{\mathrm{ABc}}$ & $0.18^{\mathrm{Aa}}$ & $0.02^{\mathrm{Dc}}$ & $0.09^{\mathrm{Aab}}$ & $0.14^{\mathrm{Dc}}$ & $0.21^{\mathrm{Aa}}$ & $0.07^{\mathrm{Cd}}$ \\
\hline \multicolumn{9}{|l|}{ Distal colon } \\
\hline \multirow{2}{*}{ Bifidobacteria } & $6.85 \pm$ & $7.90 \pm$ & $6.96 \pm$ & $8.84 \pm$ & $7.37 \pm$ & $8.44 \pm$ & $7.30 \pm$ & $8.93 \pm$ \\
\hline & $0.11^{\mathrm{Ef}}$ & $0.25^{\mathrm{Ad}}$ & $0.10^{\mathrm{Df}}$ & $0.09^{\mathrm{Ab}}$ & $0.06^{\mathrm{De}}$ & $0.05^{\mathrm{Ac}}$ & $0.08^{\mathrm{DEe}}$ & $0.15^{\mathrm{Aa}}$ \\
\hline \multirow{2}{*}{ Lactobacilli } & $6.42 \pm$ & $7.43 \pm$ & $6.83 \pm$ & $8.12 \pm$ & $6.90 \pm$ & $7.98 \pm$ & $6.82 \pm$ & $8.24 \pm$ \\
\hline & $0.05^{\mathrm{Fe}}$ & $0.12^{\mathrm{BCc}}$ & $0.13^{\mathrm{DEd}}$ & $0.15^{\mathrm{Cab}}$ & $0.14^{\mathrm{Fd}}$ & $0.10^{\mathrm{BCb}}$ & $0.05^{\mathrm{Fd}}$ & $0.10^{\mathrm{Ba}}$ \\
\hline Fecal & $8.01 \pm$ & $6.51 \pm$ & $7.95 \pm$ & $6.15 \pm$ & $7.83 \pm$ & $6.14 \pm$ & $7.49 \pm$ & $6.05 \pm$ \\
\hline coliforms & $0.28^{\mathrm{BCa}}$ & $0.07^{\mathrm{Fc}}$ & $0.08^{\mathrm{Ba}}$ & $0.07^{\mathrm{Hd}}$ & $0.10^{\mathrm{Ca}}$ & $0.04^{\mathrm{Hd}}$ & $0.11^{\mathrm{CDb}}$ & $0.05^{\mathrm{Fe}}$ \\
\hline \multirow{2}{*}{ Clostridia } & $8.20 \pm$ & $6.95 \pm$ & $8.03 \pm$ & $6.23 \pm$ & $7.90 \pm$ & $6.01 \pm$ & $7.63 \pm$ & $6.00 \pm$ \\
\hline & $0.15^{\mathrm{Ba}}$ & $0.10^{\mathrm{DEd}}$ & $0.08^{\mathrm{Bab}}$ & $0.13^{\mathrm{He}}$ & $0.12^{\mathrm{BCb}}$ & $0.10^{\mathrm{Hef}}$ & $0.05^{\mathrm{Cc}}$ & $0.04^{\mathrm{Ff}}$ \\
\hline Total & $8.58 \pm$ & $7.35 \pm$ & $8.40 \pm$ & $7.11 \pm$ & $8.12 \pm$ & $7.15 \pm$ & $8.10 \pm$ & $6.80 \pm$ \\
\hline anaerobes & $0.17^{\mathrm{Aa}}$ & $0.04^{\mathrm{Cc}}$ & $0.20^{\mathrm{Aa}}$ & $0.06^{\mathrm{Ed}}$ & $0.03^{\mathrm{Ab}}$ & $0.07^{\mathrm{Ed}}$ & $0.06^{\mathrm{Ab}}$ & $0.09^{\mathrm{De}}$ \\
\hline
\end{tabular}

Values are expressed as mean values \pm standard deviation $(n=5)$. Means in the same rows with the same lowercase letters and means in the same columns with the same uppercase letters indicate no significant difference $(P>0.05)$.

enhanced prevalence and diversity of Lactobacillus sp. communities after feeding prebiotic and probioticsupplemented vegetable beverages into a Simulator of the Human Intestinal Microbial and Ecosystem or SHIME reactor. According to some other previous studies, pectic oligosaccharides and pectin derived from orange and lemon peel, sugar beet pulp and kiwi fruit were observed to have excellent overall and bifidogenic prebiotic properties, as proven by increased probiotic populations and enhanced SCFA formation (Hotchkiss et al., 2003; Parkar et al., 2010; Gómez et al., 2014; Gómez et al., 2016).

Observing from the trends of change in the compositions of the simulated gut microbiome, the results in Table 4 elucidated a significant decrease $(P \leq 0.05)$ in the populations of fecal coliforms, clostridia and total anaerobes upon treatment with varied compositions of low-fat ice cream compared to basal conditions (control) in proximal and distal colon vessels. While feeding of the gut reactor with low-fat ice cream resulted in the least diminishing effects on harmful bacteria populations, there were no significant differences $(P>0.05)$ between reduced levels of aforementioned bacterium upon separate supplementations of low-fat ice cream with $B$. lactis $\mathrm{Bb}$ 12 and with KMN in proximal and distal colon vessels. Combined supplementation of probiotic and KMN, however, resulted in the greatest reduction in levels of clostridia, total anaerobes and fecal coliforms in both vessels. Such effects following supplementation with KMN (Treatment 3 ) and the latter in combination with $B$. lactis Bb-12 (Treatment 4) were not of significant difference $(P>0.05)$. Clear correlations between increased levels of beneficial gut bacteria and organic acids (Table 3) in the simulated gastrointestinal environment can be explained by their immunemodulatory and regulative functions, and natural inhibitory effects of common gut pathogens, including Staphylococcus aureus, Clostridium botulinum, Listeria monocytogenes, and some harmful strains of Escherichia coli (Maslowski and Mackay, 2011; Chaikham et al., 2013). Chaikham et al. (2012) reported that the probiotics or/and prebiotics possibly produced lowmolecular-weight antimicrobial substances (i.e. lactic acid, various SCFA and hydrogen peroxide) to inhibit the pathogenic bacteria. The study of Fooks and Gibson (2003) have shown enhanced antimicrobial effects, specifically inhibition of gut pathogens, E. coli and Campylobacter jejuni, by synbiotic treatments of Lactobacillus plantarum 0407 with oligofructose and Bifidobacterium bifidum with a mixture of oligofructose and xylo-oligosaccharides within an anaerobic fermentation system containing human feces. On a similar context, feeding of mice with probiotic Lactobacillus helveticus M92 and various kinds of prebiotics were shown to increase gastrointestinal populations of lactic acid bacteria, while the reduction in the levels of enterobacteria and sulphite-reducing clostridia were observed (Frece et al., 2009). 


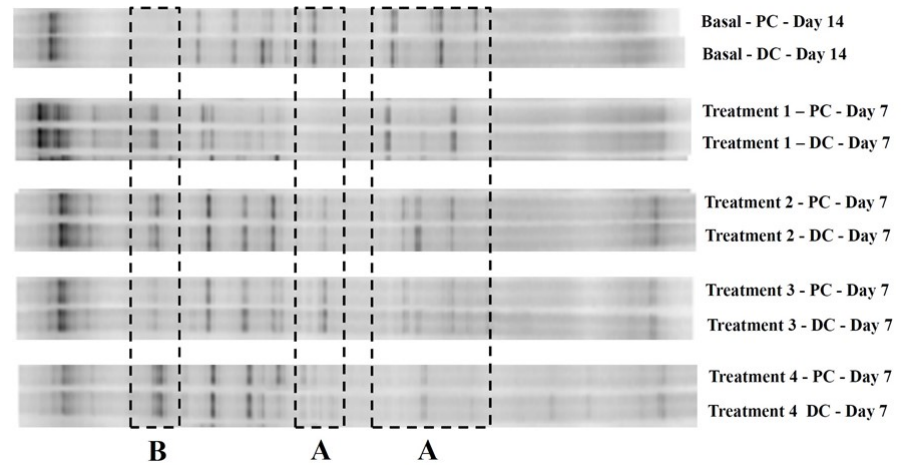

Figure 1. PCR-DGGE patterns of general colon bacteria obtained from proximal colon (PC) and distal colon (DC) compartments after feeding with different compositions of lowfat ice creams.

General colon microbial composition and population profiles were analyzed via PCR-DGCE fingerprinting of extracted bacterial DNA at Day 7 after feeding (Figure 1). Feeding of the gut reactor with pure low-fat ice cream, probiotic-supplemented and KMN supplemented low-fat ice cream has led to clear differences in PCRDCGE profile patterns compared to the basal condition. While differing band intensities and formation of new band positions were observed in all treatments on the $7^{\text {th }}$ day, the most drastic changes in band patterns occurred following treatment with combined supplementation of B. lactis $\mathrm{Bb}-12$ and $\mathrm{KMN}$ in low-fat ice cream (Treatment 4). With reference to the treatment, intensities of bacterial rRNA also clearly decreased in zone A, while some bands in zone B were intensified. Generation of such profiles validated the synergism of combined effects of $\mathrm{KMN}$ and $B$. lactis $\mathrm{Bb}-12$ supplementation on low-fat ice cream in modulating the gut microbiota. Patterns were comparable to PCR-DCGE profiles in the study of probiotic supplementations of low -fat ice cream involving a human gut reactor by Chaikham and Rattanasena (2017), where treatments of L. casei 01 and L. acidophilus LA5 strains resulted in considerable beneficial adjustments of the large intestinal microbial ecosystem. According to Bianchi et al. (2014), synbiotic vegetable beverages were found to induce changes in the composition and structure of microbial communities, especially lactobacilli, within stimulated colon compartments as observed from the increased number of bands in PCR-DCGE fingerprints. Similarly, Van Zanten et al. (2012) found that synbiotic combinations of $B$. lactis Bl-04 with melibiose, xylobiose, raffinose and maltotriose were able to shift predominant gut bacteria populations and increase their SCFA production in the colonic model system, thus may potentially be capable of manipulating the human gut microbiome. Synbiotic yogurt containing B. lactis Bb-12 and inulin could increase levels of bifidobacteria and reduce clostridia populations in a study of the human intestine by Palaria et al. (2012), using real-time PCR amplification (RT-PCR) techniques to quantify specific bacterial populations before and after yogurt treatment.

\subsection{Ammonia and biogenic amines}

Many strains of colon bacteria utilize urease, a metabolic enzyme, in converting nitrogenous compounds, including protein, peptides, amino acids and urea, into ammonia and biogenic amines (BA). BA are often formed via amino acid decarboxylation present in their biosynthetic pathways by various types of bacteria such as Enterococcus, Escherichia and Morganella strains (Mäkivuokko et al., 2010). Dairy products are prone to contain high levels of BAin the colon compartments due to its rich and balanced chemical composition, providing suitable conditions for microbial growth (Linares et al., 2011; Benkerroum, 2016). Table 5 portrays ammonia and BA formation in the colon vessels prior to and after low-fat ice cream addition. Evidently, basal concentrations of toxic nitrogenous compounds were lowest compared to low-fat ice cream treatments $(P \leq 0.05)$ in both colon vessels. Highest levels of ammonia and BA accumulation were observed in the treatment of pure low-fat ice cream (Treatment 1), while cadaverine was presented at highest levels compared to other specified BA for all treatments in both colon vessels. Pure low-fat ice cream contained skim milk and gelatin, thus may serve as major protein sources for gut bacteria in the metabolic process of substrate utilization.

Following separate treatments of low-fat ice cream with $B$. lactis Bb-12 (Treatment 2) and with KMN (Treatment 3), levels of toxic metabolites were significantly reduced $(P \leq 0.05)$ as compared to Treatment 1. Combined treatments of low-fat ice cream supplemented with B. lactis $\mathrm{Bb}-12$ and KMN (Treatment 4) contributed to a further significant diminution $(P \leq 0.05)$ in toxic compounds from previous treatments ( $\sim 0.3 \mathrm{~g} / \mathrm{L}$ and $\sim 0.7-0.9 \mathrm{~g} / \mathrm{L}$ reductions in ammonia and total BA compared to Treatment 1, respectively), although levels were still higher than basal condition (control). This may be due to the inhibitory effect of probiotic and/or KMN on the growth of BA producing bacteria. Accumulation was also greater in the distal colon vessel of the gut reactor, regardless of treatment conditions, resulting from prolonged fermentation similarly observed in the study of Chaikham and Rattanasena (2017). On the other hand, Tir Touil Meddah et al. (2001) observed an overall decline in ammonium concentration during SHIME treatment with Bifidobacterium longum whey retentate. The findings of Mäkeläinen, Forssten, Saarinen et al. (2010) demonstrated an increase in tyramine and cadaverine concentrations following semi-continuous colon model supplementation of some specific oligosaccharides, 
Table 5. Concentrations of ammonia and biogenic amines in colon vessels after supplementation with difference treatments of low-fat ice cream.

\begin{tabular}{|c|c|c|c|c|c|c|c|c|}
\hline \multirow{2}{*}{$\begin{array}{c}\text { Toxic } \\
\text { compounds (g/ } \\
\mathrm{L})\end{array}$} & \multicolumn{8}{|c|}{ Experimental periods } \\
\hline & Basal & $\begin{array}{c}\text { Treatment } \\
1\end{array}$ & Washout 1 & $\begin{array}{c}\text { Treatment } \\
2\end{array}$ & Washout 2 & $\begin{array}{c}\text { Treatment } \\
3\end{array}$ & Washout 3 & $\begin{array}{c}\text { Treatment } \\
4\end{array}$ \\
\hline \multicolumn{9}{|l|}{ Proximal colon } \\
\hline \multirow{2}{*}{ Ammonia } & $0.58 \pm$ & $1.23 \pm$ & $0.62 \pm$ & $1.15 \pm$ & $0.60 \pm$ & $1.11 \pm$ & $0.59 \pm$ & $0.97 \pm$ \\
\hline & $0.02^{\mathrm{Cd}}$ & $0.05^{\mathrm{Da}}$ & $0.01^{\mathrm{Bd}}$ & $0.03^{\mathrm{Cb}}$ & $0.06^{\mathrm{Cd}}$ & $0.02^{\mathrm{Db}}$ & $0.04^{\mathrm{Cd}}$ & $0.01^{\mathrm{Dc}}$ \\
\hline \multirow{2}{*}{ Cadaverine } & $0.43 \pm$ & $0.75 \pm$ & $0.51 \pm$ & $0.63 \pm$ & $0.49 \pm$ & $0.62 \pm$ & $0.44 \pm$ & $0.50 \pm$ \\
\hline & $0.02^{\mathrm{Dd}}$ & $0.02^{\mathrm{Fa}}$ & $0.04^{\mathrm{Cc}}$ & $0.01^{\mathrm{Eb}}$ & $0.02^{\mathrm{Dc}}$ & $0.07^{\mathrm{Eb}}$ & $0.03^{\mathrm{Ecd}}$ & $0.05^{\mathrm{Fc}}$ \\
\hline \multirow{2}{*}{ Putrescine } & $0.26 \pm$ & $0.43 \pm$ & $0.28 \pm$ & $0.35 \pm$ & $0.30 \pm$ & $0.35 \pm$ & $0.30 \pm$ & $0.31 \pm$ \\
\hline & $0.03^{\mathrm{Fd}}$ & $0.07^{\mathrm{IJa}}$ & $0.03^{\text {Ecd }}$ & $0.01^{\mathrm{Hb}}$ & $0.04^{\mathrm{Ebc}}$ & $0.05^{\mathrm{Hb}}$ & $0.05^{\mathrm{FGbc}}$ & $0.03^{\mathrm{HIbc}}$ \\
\hline \multirow{2}{*}{ Methylamine } & $0.25 \pm$ & $0.45 \pm$ & $0.30 \pm$ & $0.38 \pm$ & $0.27 \pm$ & $0.35 \pm$ & $0.28 \pm$ & $0.27 \pm$ \\
\hline & $0.01^{\mathrm{Fd}}$ & $0.04^{\text {Ia }}$ & $0.02^{\mathrm{Ec}}$ & $0.05^{\mathrm{Hab}}$ & $0.04^{\mathrm{Fcd}}$ & $0.02^{\mathrm{Hb}}$ & $0.03^{\mathrm{Gcd}}$ & $0.02^{\mathrm{Icd}}$ \\
\hline \multirow{2}{*}{ Tyramine } & $0.19 \pm$ & $0.37 \pm$ & $0.22 \pm$ & $0.32 \pm$ & $0.21 \pm$ & $0.30 \pm$ & $0.25 \pm$ & $0.24 \pm$ \\
\hline & $0.04^{\mathrm{Gd}}$ & $0.05^{\mathrm{Ja}}$ & $0.02^{\mathrm{Fcd}}$ & $0.04^{\mathrm{Ha}}$ & $0.01^{\mathrm{Gd}}$ & $0.03^{\mathrm{Ha}}$ & $0.01^{\mathrm{Gb}}$ & $0.01^{\mathrm{Jbc}}$ \\
\hline \multirow{2}{*}{$\begin{array}{c}\text { Total biogenic } \\
\text { amines }\end{array}$} & $1.22 \pm$ & $2.13 \pm$ & $1.41 \pm$ & $1.76 \pm$ & $1.38 \pm$ & $1.70 \pm$ & $1.37 \pm$ & $1.42 \pm$ \\
\hline & $0.03^{\mathrm{Bd}}$ & $0.04^{\mathrm{Ba}}$ & $0.03^{\mathrm{Ac}}$ & $0.03^{\mathrm{Bb}}$ & $0.05^{\mathrm{Bc}}$ & $0.04^{\mathrm{Bb}}$ & $0.02^{\mathrm{Bc}}$ & $0.03^{\mathrm{Bc}}$ \\
\hline \multicolumn{9}{|l|}{ Distal colon } \\
\hline \multirow{2}{*}{ Ammonia } & $0.64 \pm$ & $1.46 \pm$ & $0.63 \pm$ & $1.23 \pm$ & $0.63 \pm$ & $1.25 \pm$ & $0.60 \pm$ & $1.17 \pm$ \\
\hline & $0.05^{\mathrm{Cd}}$ & $0.08^{\mathrm{Ca}}$ & $0.06^{\mathrm{Bd}}$ & $0.07^{\mathrm{Cbc}}$ & $0.02^{\mathrm{Cd}}$ & $0.01^{\mathrm{Cb}}$ & $0.05^{\mathrm{Cd}}$ & $0.03^{\mathrm{Cc}}$ \\
\hline \multirow{2}{*}{ Cadaverine } & $0.47 \pm$ & $0.89 \pm$ & $0.57 \pm$ & $0.74 \pm$ & $0.48 \pm$ & $0.73 \pm$ & $0.51 \pm$ & $0.65 \pm$ \\
\hline & $0.03^{\mathrm{De}}$ & $0.05^{\mathrm{Ea}}$ & $0.03^{\mathrm{Cd}}$ & $0.03^{\mathrm{Db}}$ & $0.04^{\mathrm{De}}$ & $0.05^{\mathrm{Ebc}}$ & $0.03^{\mathrm{De}}$ & $0.04^{\mathrm{Ec}}$ \\
\hline \multirow{2}{*}{ Putrescine } & $0.32 \pm$ & $0.63 \pm$ & $0.40 \pm$ & $0.50 \pm$ & $0.37 \pm$ & $0.46 \pm$ & $0.38 \pm$ & $0.34 \pm$ \\
\hline & $0.04^{\mathrm{Ec}}$ & $0.01^{\mathrm{Ga}}$ & $0.04^{\mathrm{Dbc}}$ & $0.07^{\mathrm{Fb}}$ & $0.05^{\mathrm{Ec}}$ & $0.03^{\mathrm{FGb}}$ & $0.04^{\mathrm{EFc}}$ & $0.05^{\mathrm{GHc}}$ \\
\hline \multirow{2}{*}{ Methylamine } & $0.30 \pm$ & $0.59 \pm$ & $0.36 \pm$ & $0.44 \pm$ & $0.35 \pm$ & $0.43 \pm$ & $0.40 \pm$ & $0.37 \pm$ \\
\hline & $0.01^{\mathrm{Ed}}$ & $0.03^{\mathrm{Ha}}$ & $0.02^{\mathrm{Dc}}$ & $0.06^{\mathrm{Gb}}$ & $0.02^{\mathrm{EFc}}$ & $0.03^{\mathrm{Gb}}$ & $0.07^{\mathrm{EFbc}}$ & $0.01^{\mathrm{Gc}}$ \\
\hline \multirow{2}{*}{ Tyramine } & $0.26 \pm$ & $0.53 \pm$ & $0.29 \pm$ & $0.47 \pm$ & $0.33 \pm$ & $0.50 \pm$ & $0.36 \pm$ & $0.33 \pm$ \\
\hline & $0.05^{\mathrm{EFc}}$ & $0.09^{\mathrm{HIa}}$ & $0.03^{\mathrm{Ec}}$ & $0.05^{\mathrm{Ga}}$ & $0.03^{\mathrm{EFbc}}$ & $0.04^{\mathrm{Fa}}$ & $0.01^{\mathrm{Fb}}$ & $0.03^{\mathrm{GHbc}}$ \\
\hline \multirow{2}{*}{$\begin{array}{l}\text { Total biogenic } \\
\text { amines }\end{array}$} & $1.40 \pm$ & $2.75 \pm$ & $1.70 \pm$ & $2.24 \pm$ & $1.62 \pm$ & $2.20 \pm$ & $1.73 \pm$ & $1.81 \pm$ \\
\hline & $0.04^{\mathrm{Af}}$ & $0.05^{\mathrm{Aa}}$ & $0.02^{\mathrm{Ad}}$ & $0.05^{\mathrm{Ab}}$ & $0.04^{\mathrm{Ae}}$ & $0.03^{\mathrm{Ab}}$ & $0.04^{\mathrm{Ad}}$ & $0.02^{\mathrm{Ac}}$ \\
\hline
\end{tabular}

Values are expressed as mean values \pm standard deviation $(n=5)$. Means in the same rows with the same lowercase letters and means in the same columns with the same uppercase letters indicate no significant difference $(P>0.05)$.

while total BA levels remained mostly unchanged compared to baseline conditions. Additionally, Mäkeläinen, Ottman, Forssten et al. (2010) showed that probiotic B. lactis $\mathrm{Bi}-07$ supplementation alone, or in combination with polydextrose, significantly increased the production of cadaverine and spermine, while treatments of galacto-oligosaccharide showed complete suppression and reduction in the levels of specific BA in the colon simulations. In the report of Mäkivuokko et al. (2010), L. acidophilus $\mathrm{NCFM}^{\mathrm{TM}}$ plus lactitol lowered cadaverine, putrescine and total BA concentrations in the colon simulator.

While many species of probiotic bacteria are known for their therapeutic and dietetic effects, some strains of lactic acid bacteria and bifidobacteria also have the ability to decarboxylate amino acids into toxic nitrogenous metabolites (Walstra et al., 2006; Chalarampopoulos and Rastall, 2009; Buňková et al., 2011). Although the level of BA formation by bifidobacteria is relatively low, it is contrastive to preexisting beneficial dietary effects (Buňková et al., 2011). BA threatens the wellbeing of consumers by contributing to increased toxicity potential of dairy products (Lorencová et al., 2014). Chronic putrefaction from long -term protein fermentation in the colon increases the risks of colon cancer through secretions of ammonia and biogenic amines, which encourage neoplastic growth of colon epithelium and stimulate the production of cocarcinogenic phenols (Ouwehand et al., 2005). Hence, measures to reduce secretion of toxic nitrogenous compounds and bacterial proteolytic activity must be undertaken to confirm health benefits upon administration of probiotic and KMN supplemented lowfat ice cream.

\section{Conclusion}

Our findings demonstrated significant modulations of the simulated colon microbiota following feeding of the human gut reactor with $\mathrm{KMN}$ and B. lactis Bb-12 supplemented low-fat ice cream. The formation of beneficial SCFA (acetic, butyric and propionic acids) increased, along with lactic acid concentrations in both proximal and distal colon vessels, by Treatments 2-4 as compared to Treatment 1 . Both $\mathrm{KMN}$ and B. lactis $\mathrm{Bb}-$ 12 suppressed the ammonia formation and BA formation in the colon. The greater increase in populations of bifidobacteria and lactobacilli, along with declination in the levels of clostridia and fecal coliforms, were also 
observed in combined treatments of $\mathrm{KMN}$ and B. lactis Bb-12 compared to control, pure low-fat ice cream and separate supplementations of the latter. Changes in colon microbial diversity were supported by the formation of new patterns from generated PCR-DCGE fingerprints. In summary, KMN was able to boost the effects of probiotic-low-fat ice cream in improving the gut microbiota and their metabolites.

\section{Conflict of interest statement}

No conflicts of interest exist in this study.

\section{Acknowledgements}

This project was supported by the Office of the Higher Education Commission and Thailand Research Fund (Grant No. TRG5880002). A special thanks is also given to Mahidol and Phranakhon Si Ayutthaya Rajabhat Universities for scientific facilities.

\section{References}

Akalin, A.S. and Erişir, D. (2008). Effects of inulin and oligofructose on the rheological characteristics and probiotic culture survival in low-fat probiotic ice cream. Journal of Food Science, 73(4), 184-188. https://doi.org/10.1111/j.1750-3841.2008.00728.x

Apichartsrangkoon, A., Chaikham, P., Pankasemsuk, T. and Baipong, S. (2015). In vitro experiment on Lactobacillus casei 01 colonizing the digestive system in the presence of pasteurized longan juice. Acta Alimentaria, An International Journal of Food Science, 44(4), 493-500. http://dx.doi.org/10.1556/ AAlim.2015.1111

Barros, A.S., Mafra, I., Ferreira, D., Cardoso, S., Reis, A., Lopes da Silva, J.A., Delgadillo, I., Rutledge, D.N. and Coimbra, M.A. (2002). Determination of the degree of methyl-esterification of pectic polysaccharides by FT-IR using an outer product PLSI regression. Carbohydrate Polymers, 50(1), 8594. https://doi.org/10.1016/S0144-8617(02)00017-6

Benkerroum, N. (2016). Biogenic amines in dairy products: Origin, incidence, and control means. Comprehensive Reviews in Food Science and Food Safety, 15(4), 801-826. https://doi.org/10.1111/1541 $-4337.12212$

Bianchi, F., Rossi, E.A., Sakamoto, I.K., Adorno, M.A., Van de Wiele, T. and Sivieri, K. (2014). Beneficial effects of fermented vegetal beverages on human gastrointestinal microbial ecosystem in a simulator. Food Research International, 64, 43-52. https:// doi.org/10.1016/j.foodres.2014.05.072

Biavati, B. (2001). Bifidobacteria. In Biavati, B.,
Bottazzi, V., Morelli, L. and Schiavi, C. (Eds.). Microorganisms as health supporters, p. 10-33. Novara, Italy: Mofin-Alce.

Buňková, L., Buňka, F., Pollaková, E. and Podesvová, T. (2011). The effect of lactose, $\mathrm{NaCl}$ and an aero/ anaerobic environment on the tyrosine decarboxylase activity of Lactococcus lactis subsp. Cremoris and Lactococcus lactis subsp. lactis. International Journal of Food Microbiology, 147(2), 112-119. https://doi.org/10.1016/j.ijfoodmicro.2011.03.017

Çaglar, E., Kuscu, O.O., Kuwetli, S.S., Cildir, S.K., Sandalli, N. and Twetman, S. (2008). Short-term effect of ice-cream containing Bifidobacterium lactis Bb-12 on the number of salivary mutants streptococci and lactobacilli. Acta Odontologica Scandinavica, 66(3), 154-158. https:// doi.org/10.1080/00016350802089467

Chaikham, P. and Apichartsrangkoon, A. (2014). Effects of encapsulated Lactobacillus acidophilus along with pasteurized longan juice on the colon microbiota residing in a dynamic simulator of the human intestinal microbial ecosystem. Applied Microbiology and Biotechnology, 98(1), 485-495. https://doi.org/10.1007/s00253-013-4763-7

Chaikham, P. and Rattanasena, P. (2017). Combined effects of low-fat ice cream supplemented with probiotics on colon microfloral communities and their metabolites during fermentation in a human gut reactor. Food Bioscience, 17, 35-41. https:// doi.org/10.1016/j.fbio.2016.12.005

Chaikham, P., Apichartsrangkoon, A., Jirarattanarangsri, W. and Van de Wiele, T. (2012). Influence of encapsulated probiotics combined with pressurized longan juice on colon microflora and their metabolic activities on the exposure to simulated dynamic gastrointestinal tract. Food Research International, 49(1), 133-142. https://doi.org/10.1016/ j.foodres.2012.07.033

Chaikham, P., Apichartsrangkoon, A., Worametrachanon, S. and Van de Wiele, T. (2016). Impact of encapsulated Lactobacillus casei 01 along with pasteurized purple-rice drinks on modulating colon microbiome using a digestive model. International Journal of Food Engineering, 12(7), 637-646. https://doi.org/10.1007/s00253-014-5624-8

Chaikham, P., Apichartsrangkoon, A., Worametrachanon, S., Supraditareporn, W., Chokiatirote, E. and Van der Wiele, T. (2013). Activities of free and encapsulated Lactobacillus acidophilus LA5 or Lactobacillus casei 01 in processed longan juices on exposure to simulated gastrointestinal tract. Journal of the Science of Food and Agriculture, 93(9), 2229-2238. https:// 
doi.org/10.1002/jsfa.6030

Cook, S.I. and Sellin, J.H. (1998). Review article: short chain fatty acids in health and disease. Alimentary Pharmacology and Therapeutics, 12, 499-507. https://doi.org/10.1046/j.1365-2036.1998.00337.x

Cruz, A.G., Antunes, A.E.C., Sousa, A.L.O.P., Faria, J.A.F. and Saad, S.M.I. (2009). Ice-cream as a probiotic food carrier. Food Research International, 42(9), 1233-1239. https://doi.org/10.1016/ j.foodres.2009.03.020

den Besten, G., van Eunen, K., Groen, A.K., Venema, K., Reijngoud, D.J. and Bakker, B.M. (2013). The role of short-chain fatty acids in the interplay between diet, gut microbiota, and host energy metabolism. The Journal of Lipid Research, 54, 2325-2340. https://doi.org/10.1194/jlr.R036012

Fooks, L.J. and Gibson, G.R. (2003). Mixed culture fermentation studies on the effects of synbiotics on the human intestinal pathogens Campylobacter jejuni and Escherichia coli. Anaerobe, 9(5), 231-242. https://doi.org/10.1016/S1075-9964(03)00043-X

Frece, J., Kos, B., Svetec, I.K. and Zgaga, Z. (2009). Synbiotic effect of Lactobacillus helveticus M92 and prebiotics on the intestinal microflora and immune system of mice. Journal of Dairy Research, 76(1), 98-104. S0022029908003737

Gibson, G.R. (2004). Fibre and effects on probiotics (the prebiotic concept). Clinical Nutrition Supplements, 1 (2), 25-31. https://doi.org/10.1016/ j.clnu.2004.09.005

Gómez, B., Gullón, B., Remoroza, C., Schols, H.A., Parajó, J.C. and Alonso, J.L. (2014). Purification, characterization, and prebiotic properties of pectic oligosaccharides from orange peel wastes. Journal of Agricultural and Food Chemistry, 62(40), 97699782. https://doi.org/10.1021/jf503475b

Gómez, B., Gullón, B., Yáñez, R., Schols, H. and Alonso, J.L. (2016). Prebiotic potential of pectins and pectic oligosaccharides derived from lemon peel wastes and sugar beet pulp: A comparative evaluation. Journal of Functional Foods, 20, 108121. https://doi.org/10.1016/j.jff.2015.10.029

Granato, D., Branco, G.F., Cruz, A.G., Faria, J.D.A.F. and Shah, N.P. (2010). Probiotic dairy products as functional foods. Comprehensive Reviews in Food Science and Food Safety, 9(5), 455-470. https:// doi.org/10.1111/j.1541-4337.2010.00120.x

Ho, Y.Y., Lin, C.M. and Wu, M.C. (2017). Evaluation of the prebiotic effects of citrus pectin hydrolysate. Journal of Food and Drug Analysis, 25(3), 550-558. https://doi.org/10.1016/j.jfda.2016.11.014
Hotchkiss, J.A.T., Olano-Martin, E., Grace, W.E., Gibson, G.R. and Rastall, R.A. (2003). Pectic oligosaccharides as prebiotics. ACS Symposium Series, 849, 54-62. https://doi.org/10.1021/bk-20030849.ch005

Kontula, P., Nollet, L., Saarela, M., Vilpponen-Salmela, T., Verstraete, W., Mattila- Sandholm, T. and von Wright, A. (2002). The effect of lactulose on the survival of Lactobacillus rhamnosus in the simulator of the human intestinal microbial ecosystem $\left(\mathrm{SHIME}^{\circledR}\right)$ and in vivo. Microbial Ecology in Health and Disease, 14(2), 90-96. https:// doi.org/10.1080/08910600260081739

Linares, D.M., Martín, M.C., Ladero, V., Alvarez, M.A. and Fernández, M. (2011). Biogenic amines in dairy products. Critical Reviews in Food Science and Nutrition, 51(7), 691-703. https:// doi.org/10.1080/10408398.2011.582813

Liong, M.T., Fung, W.Y., Ewe, J.A., Kuan, C.Y. and Lye, H.S. (2009). The improvement of hypertension by probiotics: Effects on cholesterol, diabetes, renin, and phytoestrogens. International Journal of Molecular Science, 10(9), 3755-3775. https:// doi.org/10.3390/ijms10093755

Lorencová, E., Buňková, L., Pleva, P., Dráb, B., Kubáň, V. and Buňka, F. (2014). Selected factors influencing the ability of Bifidobacterium to form biogenic amines. International Journal of Food Science and Technology, 49(5), 1302-1307. https:// doi.org/10.1111/ijfs. 12427

MacFarlane, G.T. and Gibson, G.R. (1995). Microbiological aspects of the production of shortchain fatty acids in the large bowel. In Cummings, J.H., Rombeau, J.L. and Sakata, S. (Eds.). Physiological and clinical aspects of short-chain fatty acids, p. 87. Cambridge, UK: Cambridge University Press.

MacFarlane, G.T., Gibson, G.R. and Cummings, J.H. (1992). Comparison of fermentation reactions in different regions of the human colon. Journal of Applied Bacteriology, 72(1), 57-64. https:// doi.org/10.1111/j.1365-2672.1992.tb04882.x

Mäkeläinen, H., Forssten, S., Saarinen, M., Stowell, J., Rautonen, N. and Ouwehand, A.C. (2010). Xylooligosaccharides enhance the growth of bifidobacteria and Bifidobacterium lactis in a simulated colon model. Beneficial Microbes, 1(1), 81 -91. https://doi.org/10.3920/BM2009.0025

Mäkeläinen, H., Ottman, N., Forssten, S., Saarinen, M., Rautonen, N. and Ouwehand, A.C. (2010). Synbiotic effects of galacto-oligosaccharide, polydextrose and Bifidobacterium lactis Bi-07 in vitro. International Journal of Probiotics and Prebiotics, 5(4), 203-210. 
Mäkivuokko, H., Forssten, S., Saarinen, M., Ouwehand, A. and Rautonen, N. (2010). Synbiotic effects of lactitol and Lactobacillus acidophilus $\mathrm{NCFM}^{\mathrm{TM}}$ in a semi-continuous colon fermentation model. Beneficial Microbes, 1(2), 131-137. https:// doi.org/10.3920/BM2009.0033

Mäkivuokko, H., Kettunen, H., Saarinen, M., Kamiwaki, T., Yokoyama, Y., Stowell, J. and Rautonen N. (2007). The effect of cocoa and polydextrose on bacterial fermentation and growth in gastrointestinal tract simulations. Bioscience, Biotechnology and Biochemistry, 71(8), 1834-1843. https:// doi.org/10.1271/bbb.60706

Mäkivuokko, H., Saarinen, M., Ouwehand, A. and Rautonen, N. (2006). Effects of lactose on colon microbial community structure and function in a four -stage semi-continuous culture system. Bioscience, Biotechnology and Biochemistry, 70(9), 2056-2063. https://doi.org/10.1271/bbb.60022

Maslowski, K.M. and Mackay, C.R. (2011). Diet, gut microbiota and immune responses. Nature Immunology, 12, 5-9. https://doi.org/10.1038/ni0111 $-5$

Ouwehand, A.C., Derrien, M., de Vos, W., Tiihounen, K. and Rautonen, N. (2005). Prebiotics and other microbial substrates for gut functionality. Current Opinion in Biotechnology, 16(2), 212-217. https:// doi.org/10.1016/j.copbio.2005.01.007

Palaria, A., Johnson-Kanda, I. and O'Sullivan, D.J. (2012). Effect of a synbiotic yogurt on levels of fecal bifidobacteria, clostridia, and enterobacteria. Applied and Environmental Biology, 78(4), 933-940. https:// doi.org/10.1128/AEM.05848-11

Parkar, S.G., Redgate, E.L., Wibisono, R., Luo, X., Koh, E.T.H. and Schröder, R. (2010) Gut health benefits of kiwifruit pectins: Comparison with commercial functional polysaccharides. Journal of Functional Foods, 2(3), 210-218. https://doi.org/10.1016/ j.jff.2010.04.009

Pokusaeva, K., Fitzgerald, G.F. and van Sinderen, G. (2011). Carbohydrate metabolism in bifidobacteria. Genes and Nutrition, 6(3), 285-306. https:// doi.org/10.1007/s12263-010-0206-6

Possemiers, S., Marzorati, M., Verstraete, W. and Van de Wiele, T. (2010). Bacteria and chocolate: A successful combination for probiotic delivery. International Journal of Food Microbiology, 141(12), 97-103. https://doi.org/10.1016/ j.ijfoodmicro.2010.03.008

Prado, F.C., Parada, J.L., Pandey, A. and Soccol, C.R. (2008). Trends in non-dairy probiotic beverages. Food Research International, 41(2), 111-123. https://doi.org/10.1016/j.foodres.2007.10.010

Shah, N.P. (2007). Functional cultures and health benefits. International Dairy Journal, 17(11), 12621277. https://doi.org/10.1016/j.idairyj.2007.01.014

Singthong, J., Cui, S.W., Ningsanond, S. and Goff, H.D. (2004). Structural characterization, degree of esterification and some gelling properties of Krueo Ma Noy (Cissampelos pareira) pectin. Carbohydrate Polymers, 58(4), 391-400. https://doi.org/10.1016/ j.carbpol.2004.07.018

Singthong, J., Ningsanond, S., Cui, S.W. and Goff, H.D. (2005). Extraction and physiochemical characterization of Krueo Ma Noy pectin. Food Hydrocolloids, 19(5), 793-801. https:// doi.org/10.1016/j.foodhyd.2004.09.007

Sivieri, K., Morales, M.L.V., Adorno, M.A.T., Sakamoto, I.K., Saad, S.M.I. and Rossi, E.A. (2013). Lactobacillus acidophilus CRL 1014 improved "gut health" in the SHIME $^{\circledR}$ reactor. Gastroenterology, 13, 100-109. https://doi.org/10.1186/1471-230X-13100

Slavin, J. (2013). Fiber and prebiotics: Mechanisms and health benefits. Nutrients, 5(4), 1417-1435. https:// doi.org/10.3390/nu5041417

Tir Touil Meddah, A., Yazourh, A., Desmet, I., Risbourg, B., Verstraete, W. and Romond, M.B. (2001). The regulatory effects of whey retentate from bifidobacteria-fermented milk on the microbiota of the simulator of the human intestinal microbial ecosystem (SHIME). Journal of Applied Microbiology, 91(6), 1110-1117. https:// doi.org/10.1046/j.1365-2672.2001.01482.x

Topping, D.L. and Clifton, P.M. (2001). Short-chain fatty acids and human colonic function: Roles of resistant starch and nonstarch polysaccharides. Physiological Reviews, 81(3), 1031-1064. https:// doi.org/10.1152/physrev.2001.81.3.1031

Tosukhowong, A., Visessanguan, W., Pumpuang, L., Tepkasikul, P., Panya, A. and Valyasevi, R. (2011). Biogenic amine formation in Nham, a Thai fermented sausage, and the reduction by commercial starter culture, Lactobacillus plantarum BCC 9546. Food Chemistry, 129(3), 846-853. https:// doi.org/10.1016/j.foodchem.2011.05.033

Van de Wiele, T., Boon, N., Possemiers, S., Jacobs, H. and Verstraete, W. (2006). Inulin-type fructans of longer degree of polymerization exert more pronounced in vitro prebiotic effects. Journal of Applied Microbiology, 102(2), 452-460. https:// doi.org/10.1111/j.1365-2672.2006.03084.x

Van Immerseel, F., Ducatelle, R., De Vos, M., Boon, N., Van De Wiele, T., Verbeke, K., Rutgeerts, P., Sas, 
B., Louis, P. and Flint H.J. (2010). Butyric acidproducing anaerobic bacteria as a novel probiotic treatment approach for inflammatory bowel disease. Journal of Medical Microbiology, 59, 141-143. https://doi.org/10.1099/jmm.0.017541-0

Van Zanten, G.C., Knudsen, A., Röytiö, H., Forssten, S., Lawther, M., Blennow, A., Lahtinen, S.J., Jakobsen, M., Svensson, B. and Jespersen, L. (2012). The effect of selected synbiotics on microbial composition and short-chain fatty acid production in a model system of the human colon. PLoS One, 7 (10), e47212. https://doi.org/10.1371/ journal.pone. 0047212

Walstra, P., Wouters, J.T. and Gurts, T.J. (2006). Dairy science and technology, p. 571. New York: Taylor and Francis.

Woods, M.N. and Gorbach, S.L. (2001). Influences of fibre on the ecology of the intestinal flora. In Spiller, G.A. (Ed.), Handbook of dietary fibre in human nutrition, p. 257-270. Boca Raton, FL: CRC Press. 